Wilfrid Laurier University

Scholars Commons @ Laurier

$5-1-1988$

\title{
Assessing National Human Rights Performance: A Theoretical Framework
}

Jack Donnelly

University of North Carolina Chapel Hill

Rhoda E. Howard-Hassmann

Wilfrid Laurier University, hassmann@wlu.ca

Follow this and additional works at: https://scholars.wlu.ca/poli_faculty

\section{Recommended Citation}

Donnelly, Jack and Howard-Hassmann, Rhoda E., "Assessing National Human Rights Performance: A Theoretical Framework" (1988). Political Science Faculty Publications. 21.

https://scholars.wlu.ca/poli_faculty/21

This Article is brought to you for free and open access by the Political Science at Scholars Commons @ Laurier. It has been accepted for inclusion in Political Science Faculty Publications by an authorized administrator of Scholars Commons@ Laurier. For more information, please contact scholarscommons@wlu.ca. 


\title{
Assessing National Human Rights Performance: A Theoretical Framework*
}

\author{
Jack Donnelly \\ Rhoda E. Howard
}

Comparative quantitative assessment of human rights is hampered by the length of the list of internationally recognized rights. Not only is the list so long that it is hard to imagine gathering adequate data without an army of researchers (the International Human Rights Covenants contain more than thirty substantive articles, encompassing at least twice as many separate rights), but the results of such a comprehensive effort would almost certainly be overwhelming and bewildering in their complexity. In this article we try to narrow the list of rights concerning which it is necessary to gather data by establishing a theoretical framework for assessing a state's human rights performance. We identify a relatively small set of ten essential rights that separately are intrinsically essential and together provide good proxies for almost all other rights. An assessment of national performance on these ten rights, we argue, will approximate a comprehensive assessment of a country's overall human rights record.

\section{A "SHORT-LIST" OF RIGHTS}

Our "short list" of ten rights can be grouped into four categories:

- "Survival" rights, which guarantee individual existence: rights to life, food and health care.

- "Membership" rights, which assure one an equal place in society: family rights and the prohibition of discrimination.

\footnotetext{
* We thank Philip Alston, Peter Baehr, David Forsythe, James Hathaway, William Keech, Bert Lockwood, Kim Nossal, Cranford Pratt, Kathleen Pritchard, John Vincent, Jane Vock, Claude Welch, James White and Gordon Whitaker for comments on an earlier draft.
} 
- "Protection" rights, which guard the individual against abuses of power by the state: rights to habeas corpus and an independent judiciary.

- "Empowerment" rights, which provide the individual with control over the course of his or her life, and in particular, control over (not merely protection against) the state: rights to education, a free press, and freedom of association.

This list implies no hierarchy of rights. Quite the contrary, a recurring theme in what follows is the interdependence of all human rights. Survival rights, listed first, are no more, and no less, basic or important than empowerment rights, listed last. Although no rights can be enjoyed unless one is alive, the right to life has no moral priority; it may be a prerequisite to enjoying other rights, but that does not make it a "higher" right. Likewise, although we argue below that a free press and freedom of association are most effective in securing political guarantee of other rights, that gives these rights at most a political, not a moral priority. Furthermore, these ten rights are not necessarily more important than other human rights For example, we argue that family rights, a free press, and freedom of association can stand as proxies for the right to religion, but this does not imply that they are of higher moral value.

We claim only a methodological priority for these rights: taken together they can stand as measures of performance for virtually the entire list of internationally recognized human rights. Because of certain logical, political, and moral linkages among the rights discussed below, we contend that a state which protects these rights probably will be found to protect most other human rights as well. If this is true, national assessments will be greatly simplified. Such simplification, and the more coherent direction it can provide to research, is the ultimate aim and justification of our theoretical work here.

Clearly our project implies acceptance of the cross-national normative consensus represented by the International Bill of Human Rights (the Universal Declaration of Human Rights [1948] and the International Human Rights Covenants [1966]). For practical purposes, the endorsement of this list by virtually all states, whatever their shortcomings in living up to its demands, precludes using any other list. Fortunately, the list is a remarkably good one. It includes a wide range of civil and political as well as economic, social, and cultural rights. Furthermore, as we have argued elsewhere the full list can easily be derived from the principles of autonomy and moral equality and it provides a plausible account of the prerequisites of a life of dignity - at least in comtemporary state societies, which will be our exclusive focus here. The International Bill of Human Rights may not be complete or

1. Rhoda E. Howard and Jack Donnelly, "Human Dignity, Human Rights and Political Regimes," American Political Science Review 80 (September 1986): 805-806. 
fully adequate (e.g., nonarbitrary capital punishment is allowed and the rights of homosexuals are not guaranteed) but, henceforth, we will treat it as specifying the rights that must be encompassed in any comprehensive assessment of national practices.

In addition to its intrinsic significance, this project is important because of the role human rights assessments have come to play in foreign and domestic policy. A number of Western countries, such as the United States, Norway, and the Netherlands, ${ }^{2}$ now tie foreign aid more or less closely to human rights performance, and the general tenor of relations can be greatly affected by perceptions of a country's human rights practices. No less importantly, a country's own human rights practices can raise major domestic political issues. Assessments based on information systematically gathered and presented according to a sound theoretical framework may allow policymakers the opportunity to take into account most of the essential information.

Quantitative indicators and evaluative assessments of various sorts are already being demanded, produced and used, and in the United States at least, have been formally incorporated into the foreign policy process. ${ }^{3}$ Social scientists thus have an obligation to provide analysts and policymakers with the clearest possible indicators. The essential first step in this process is the identification of a manageable, theoretically defensible set of human rights with which to assess national human rights practices. ${ }^{4}$

2. See, for example, Tor Skälnes and Jan Egeland, ed., Human Rights in Developing Countries 1986 (Oslo: Norwegian University Press, 1986); and Peter Baehr, "Concern for Development Aid and Fundamental Human Rights: The Dilemma Faced by the Netherlands," Human Rights Quarterly 4 (Spring 1982): 39-52.

3. Judith Innes de Neufville, "Human Rights Reporting as a Policy Tool: An Examination of the State Department Country Reports," Human Rights Quarterly 8 (November 1986): 681699; and Gloria Valencia-Weber and Robert J. Weber, "El Salvador: Methods Used to Document Human Rights," Human Rights Quarterly 8 (November 1986), 731-770.

4. We are particularly troubled by the tendencies in the recent literature on measuring human rights to use arbitrary definitions and to make questionable use of data developed for other purposes. For example, David L. Banks ("The Analysis of Human Rights Data Over Time," Human Rights Quarterly 8 [November 1986]: 654-655) claims to be talking about human rights but in fact simply takes "political freedom" to be equivalent to human rights without providing any argument at all. Kenneth A. Bollen ("Political Rights and Political Liberties in Nations: An Evaluation of Human Rights Measures," Human Rights Quarterly 8 [November 1986]: 567-591) advocates use of his political democracy index, developed for other purposes, although the link between this index and internationally recognized human rights remains obscure. The use of the PQLI (Physical Quality of Life Index) as a general measure of economic and social rights performance (see, for example, Kathleen Pritchard, "Comparative Human Rights: An Integrative Explanation," Policy Studies Journal 15 [September 1986]: 110-122) also is troublesome, because the variables included in the measure are strongly intercorrelated; it does not measure distributional inequalities in a society; and it is only vaguely linked to internationally accepted human rights. For a good review of problems in measuring human rights performance, especially with data gathered for other purposes, see Robert Justin Goldstein, "The Limitation of Using Quantitative Data in Studying Human Rights Abuses," Human Rights Quarterly 8 (November 1986): 607-627. 
TABLE 1

Survival Rights

\begin{tabular}{ll}
\hline \hline \multicolumn{1}{c}{ Right to } & \multicolumn{1}{c}{ Proxy for } \\
\hline LIFE (D3, C6) & Torture (D5, C7) \\
FOOD (D25, E11) & Property (D17) \\
HEALTH CARE (D25, E12) & Social Security (D22, E9) \\
& Mothers and Children (D25) \\
\hline
\end{tabular}

Note: The source of each right in the International Bill of Human Rights is indicated in parentheses, by article number and document $(D=$ Universal Declaration of Human Rights; $E=$ International Covenant on Economic, Social and Cultural Rights; C = International Covenant on Civil and Political Rights).

The following four sections examine in detail our ten key rights. Each section begins with a brief discussion of the general importance of that category of human rights and a table that specifies the sources of each right in the Covenants and the Universal Declaration and indicates the other rights for which it can be used as a proxy. Each right is then discussed, with attention given to its intrinsic importance, the ways it may stand for rights not included on the short list, and its interaction with other rights. Finally, we discuss a handful of internationally recognized human rights that are not adequately encompassed by our short list.

\section{SURVIVAL RIGHTS}

Because survival is prerequisite to all other human rights, rights that guarantee survival must be included in any short list of human rights. We have identified three key survival rights: the right to life, which we interpret as a right to protection against death at the hands of another (especially the state); the right to food, the right to the minimum supplies of sustenance; and the right to health care. These rights, and the rights for which they may be deemed proxies are set out in Table 1.

\section{The Right to Life}

Article 6 of the International Covenant on Civil and Political Rights states that "every human being has the inherent right to life. This right shall be protected by law. No one shall be arbitrarily deprived of his life." The right to life, expressed in similar terms in Article 3 of the Universal Declaration, is probably the single least controversial human right -in theory. In practice, 
however, it is regularly, often flagrantly and systematically, violated. Leo Kuper has argued, with some justification, that "[the right to life] is one of the most abused of human rights - abused above all by governments, the political custodians and protectors of human rights." 5

Some commentators argue for a very broad interpretation of the right to life as encompassing numerous other rights explicitly recognized elsewhere in the International Bill. ${ }^{6}$ We prefer to stick closely to the words of the Covenant and focus on legal protection against arbitrary deprivations of life. This requires state guarantees of minimal conditions of social order, protection against private murders, and protection against execution by the state or its agents.

Social order is often taken for granted, but when it breaks down even the framework for existence collapses. Life, however, does not simply degenerate into an atomistic war of all against all. Rather, organized elements, often more or less closely attached to the state or its remnants, are loosed on society, placing the lives of individuals at risk not so much from their neighbors as from gangs of armed men who replace legitimate social order with personal rule based on force. In an extreme case, such as contemporary Lebanon, the state gives way to ethnic, religious, and political private militias. ${ }^{7}$ Protection against such a world requires a state capable of untempered and illegitimate use of force, providing law and order. Life can be guaranteed only when the "politics" of force and terror is replaced by more or less legitimate political order.

In addition to providing minimal social order, the right to life requires the state to protect individuals against attacks on their person either by fellow citizens or the state and its agents. Laws prohibiting murder and violent assaults are necessary, along with a judiciary and police force capable of enforcing such prohibitions.

The state must also assure that its own officials or agents are prevented from killing civilians (and each other). ${ }^{8}$ In recent years, such killing has taken

5. Leo Kuper, "Genocide and Mass Killing: Illusion and Reality," in The Right to Life in International Law, ed. B. G. Ramcharan (Dordrecht: Martinus Nijhoff, 1985).

6. See, for example, B. G. Ramcharan, "The Concept and Dimensions of the Right to Life," in Ramcharan ed., note 5 above.

7. Douglas duCharme, "Lebanon," in International Handbook on Human Rights, ed. Jack Donnelly and Rhoda E. Howard (Westport, CT: Greenwood Press, 1987).

8. Although Article 6 of the Civil and Political Covenant does explicitly allow capital punishment in limited circumstances - an allowance underscored by the prohibition only of "arbitrary" deprivations of life-we would argue that considerations of morality and logical consistency require prohibiting judicial as well as extrajudicial executions. Even in cases of the most heinous crimes, we would argue that simple logical consistency requires prohibition even of nonarbitrary, judicially sanctioned executions. The idea of human rights - equal and inalienable rights held by each person simply as a human being - implies an inherent and irreducible moral value in each person that the state must respect. The death penalty, even if applied "fairly," is morally problematic because of its complete and final denial of this value. Ongoing discussions concerning the drafting of a Second Optional 
on gruesome new forms, as witnessed by the rise of death squads and "disappearances" in Latin America and elsewhere, and the practice of "salvaging" in the Philippines. ${ }^{9}$ These have not, however, supplanted more conventional practices of mass murder and genocide. In addition to relatively well reported cases such as Kampuchea (1975-78), and the excesses of dictators such as Bokassa in the Central African "Empire" or Macias Nguema in Equatorial Guinea, there are numerous other examples, such as the systematic massacres of Indians in Paraguay and Guatemala, and two waves of horrible mass murders in less than twenty years in Indonesia: in 1965 through 1966, when roughly half a million leftists were killed, and in the late seventies and early eighties, when at least one-quarter, and probably closer to half, of the population of East Timor died when it was forcibly incorporated into Indonesia. ${ }^{10}$ Significant numbers of official and quasiofficial murders have occurred in literally dozens of other countries. ${ }^{11}$

No guarantee of the right to life can ever be absolutely certain. Nevertheless, a state that does not take action to prevent murder and violent crime is not discharging its responsibilities with respect to the right to life. For example, the failure of the government to prosecute a single person for the disappearance and death of even one of the tens of thousands of Salvadoran victims of death squads, and the failure of some urban police forces in the United States to provide adequate protection to selected neighborhoods and public housing projects, represent clear violations of the right of life.

The right to life requires actual as well as legislative protection. In some cases, scarcity of resources may take the prevention of certain kinds of violations too costly for the state to act effectively. For example, at some point the marginal utility of increased police protection becomes so small

Protocol to the Covenant prohibiting capital punishment (See U.N. Commission on Human Rights Resolution 1987/104 and UN document E/CN.4/Sub.2/1987/20) may indicate a turn of international law and opinion in this direction.

9. See Amnesty International USA, Disappearances: A Workbook (New York: Amnesty International, 1981); Edy Kaufman and Patricia Weiss Fagen, "Extrajudicial Executions: An Insight into the Global Dimensions of a Human Rights Violation," Human Rights Quarterly 3 (November 1981): 81-100; Richard P. Claude, "The Philippines," in Donnelly and Howard ed., note 7 above; and Report of the Working Group on Enforced or Involuntary Disappearances, UN document E/CN.4/1987/15.

10. Eric Wolf, "Murder of the Ache," in Genocide in Paraguay, ed. Philip Arens (Philadelphia: Temple University Press, 1976); Gordon L. Bowen, "The Political Economy of State Terrorism: Barrier to Human Rights in Guatemala," in Human Rights and Third World Development, ed. George W. Shepherd and Ved P. Nanda (Westport, CT: Greenwood Press, 1985). A. Kohen and J. Taylor, An Act of Genocide: Indonesia's Invasion of East Timor (London: TAPOL, 1979); James Dunn, Timor: A People Betrayed (Milton, Qld: Jacaranda, 1983); and C. Budiardjo and L. Liong, The War Against East Timor (London: Zed Press, 1984).

11. See, for example, Michael Stohl and George A. Lopez, ed., The State as Terrorist: The Dynamics of Governmental Violence and Repression (Westport, CT: Greenwood Press, 1984); Amnesty International, Political Killings by Governments (London: Amnesty International Publications, 1983); and UN document E/CN.4/1987/20. 
that even very wealthy societies are likely to find better uses for scarce public resources. But such limiting cases-which exist for all rights-must be the exception only. Protection of the right to life requires not only that state officials refrain from threatening the lives of citizens, but also that police, prosecutors, courts, and any other necessary institutions, take positive action to assure that citizens are safe from threats of violence, regardless of their source.

The right to life may be a prerequisite to the enjoyment of all other rights. It is, however, such a minimal guarantee of human dignity - if the right to life is the only right guaranteed in contemporary state societies, life may not necessarily be short, but it may be solitary, poor, nasty, and brutishthat it does not serve as much of a proxy or indicator for other human rights. The one partial exception is the right to protection against torture, which can result in death, and in every case involves the treatment of individuals as less than human beings. States may torture citizens while protecting their right to life; indeed, there are state-employed physicians in countries such as Chile and the Soviet Union whose job is to ensure that torturers can inflict the maximum amount of pain without actually killing their victims. ${ }^{12}$ But a moral and political ethos that rejects as illegitimate the taking of life (as opposed to mere judgments of expediency about when or when not to torture someone to death) will be one that for similar reasons rejects torture as a legitimate instrument of state policy.

\section{The Right to Food}

Article 11 of the International Covenant on Economic, Social and Cultural Rights recognizes "the right of everyone to an adequate standard of living for himself and his family, including adequate food, clothing and housing," as well as "the fundamental right of everyone to be free from hunger." The right to food is generally considered to be the "economic" equivalent of the right to life-death from starvation is no less death than if one is shot-and many of the arguments made above apply here too. For example, guaranteeing the right to food requires analogous protections of social order as well as protection against both private and quasi-official theft of land and other resources.

12. David Kowalewski, "Union of Soviet Socialist Republics," in Donnelly and Howard ed., note 7 above; Eric Stover and Elena O. Nightingale, Breaking Bodies and Minds (San Francisco: W. Freeman, 1986); Eric Stover, The Open Secret: Torture and the Medical Profession in Chile (Washington, DC: American Association for the Advancement of Science, July 1987); and UN document E/CN.4/1987/13, paras. 23-34. On the problem of torture more generally, see Amnesty International, Torture in the Eighties (London: Amnesty International Publications, 1984). 
Although it is often argued that the right to food is more difficult for states to honor than the right to life, especially in poor countries, all reasonable assessments suggest that there is plenty of food in the world for everyone. Moreover, the right to food is at issue not only in poor countries, but also in rich ones such as the United States. ${ }^{13}$ The availability of food is a matter of equitable inter- and intra-national distribution, less a matter of resource scarcity than political choice. ${ }^{14}$ It is also increasingly a matter of access to land, or the deprivation of such access. From the forcible removal of peasants in rebel areas of Ethiopia to the marginalization of peasants in favor of multinational agribusiness in Central America, deprivation of land use is often the key to deprivation of food..$^{15}$

Therefore, we suggest an inversion of the standard liberal account of the link between the right to food and the right to property (which is also discussed in Section 6 below). We agree with Shue ${ }^{16}$ that the right to food or subsistence "trumps" the right to property, as implied, perhaps, by the elimination of the right to property from the 1966 Covenants, despite its inclusion in the 1948 Universal Declaration. Nevertheless, in a world still inhabited by billions of peasants, protection of a family's property or use rights in land may well constitute one of the best protections of the right to food. Similarly, the redistribution of land from large holders to peasant families or cooperatives may facilitate enjoyment of the right to food. Even very poor states, which usually lack the administrative capacity to ensure by direct action that all their citizens are fed, can help to protect the right by creating or preserving legal protection of citizens' access to land.

This argument can be extended to individuals' rights to "property" in the industrialized world, where personal and social wages are the closest many citizens come to the ownership of "property". In such societies, state policies such as minimum wage or guaranteed income legislation can protect this essential personal "property" and ensure that citizens can obtain food.

13. Asbjorn Eide, Report on the Right to Adequate Food as a Human Right, UN document E/CN.4/Sub.2/1987/23; Martha H. Good, "Freedom from Want: The Failure of United States Courts to Protect Subsistence Rights," Human Rights Quarterly 6 (August 1984): 355-65; and Robert Justin Goldstein, "The United States of America," in Donnelly and Howard ed., note 7 above.

14. Cheryl Christensen, The Right to Food: How to Guarantee (New York: Institute for World Order, 1978); and Independent Commission on International Development Issues [Brandt Commission], North-South: A Program for Survival (Cambridge: MIT Press, 1983): chap. 5.

15. Peter Niggli, Ethiopia: Deportations and Forced-Labour Camps ([West] Berlin: Berliner Missionwerk, January 1986); Jim Doble, Resettlement in Ethiopia: An Independent Study into the Plight of Ethiopia's Refugees (Toronto: Energy Probe, 1986); and Charles D. Brockett, "The Right to Food and United States Policy in Guatemala," Human Rights Quarterly 6 (August 1984): 366-380.

16. Henry Shue, Basic Rights: Subsistence, Affluence and U.S. Foreign Policy (Princeton: Princeton University Press, 1980): 125. 


\section{The Right to Health Care}

For life to be anything other than the mere minimum of brutish existence, access to health care is essential. Article 12 of the International Covenant on Economic, Social and Cultural Rights recognizes "the right of everyone to the enjoyment of the highest attainable standard of physical and mental health." The phrase "highest attainable," like the general obligation in Article $2(1)$ of states parties "to achieve progressively the full realization of the rights to the maximum of its available resources," suggests not merely a long term and progressively rising requirement but also immediate demands specific to the resources available to each state. ${ }^{17}$

The right to health care requires that all medically unnecessary physical suffering be prevented. By "unnecessary" we mean physical suffering that readily available national and internationa ${ }^{18}$ health care systems could prevent. For example, World Health Organization "packages" of immunization and public health measures have succeeded, in countries such Nicaragua, in reducing infant mortality rates very quickly. ${ }^{19}$

The right to health care is a good partial proxy for the rights of mothers and children to special protection. For example, in the Soviet Union the physically abusive manner in which the state provides birth control, through multiple abortions instead of contraceptive devices, has resulted in an unprecedented rise in the infant mortality rate in the $1970 \mathrm{~s} .{ }^{20}$ Similarly, in the United States-perhaps the only Western industrialized democracy not to provide universal child allowances, job-protected maternity leaves, and taxsupported universal prenatal care-infant mortality rates in some black ghettos and rural areas now rival or exceed those of many Third World countries. ${ }^{21}$

In addition, adequate health care cannot be made available to all members of a society without a comprehensive social security package. The aged, infirm, and unemployed, as well as mothers and children, require social security protection to maintain their health. Thus, a state that is genuinely committed to providing the basic right to health probably will also provide a full range of social security protections.

Adequate safeguards of the rights to food and health care are likely to be mutually reinforcing. Most obviously, malnutrition can be an important factor in susceptibility to many diseases. Conversely, a population well protected against common debilitating diseases by a program of preventive

17. Limburg Principles on the Implementation of the International Covenant on Economic, Social and Cultural Rights, UN document E/CN.4/1987/17 Annex, paras. 21-28. (Reprinted in Human Rights Quarterly 9 [May 1987]: 122-135.)

18. Ibid., para. 26, 29-34.

19. Catherine Gander, "Nicaragua," in Donnelly and Howard ed., note 7 above.

20. Kowalewski, note 12 above, and Cullen Murphy, "Watching the Russians," Atlantic 251 (February 1983): 51.

21. Goldstein, note 13 above. 
public health care may be better able to satisfy its food needs. For example, effective programs against water-borne diseases such as schistosomiasis (bilharzia) could prevent literally hundreds of thousands from becoming needlessly disabled, and thus enable them to cultivate their own food.

\section{MEMBERSHIP RIGHTS}

The protection of survival rights alone guarantees only the crudest anomic existence, a life unfit for a human being; to exist as a human being, one must exist as part of a community. From Aristotle to Marx it has been commonplace, yet absolutely essential to note that man is a social animal. More recently, it has been noted that women and children, too, are part of the community.

The destruction of families and communities ranks high on every sociological list of state actions that "ordinary" people consider to be abusive of human rights. ${ }^{22}$ Families are normally a part of communities, sharing common ethnic features, including religious beliefs, social customs, languages, and myths of origin or ancestry. Indeed, in many preindustrial societies families and communities are one, since myths of extended kinship tie nuclear families into larger clans or tribes. In contemporary nation-states, symbols of patriotism and citizenship often substitute for these preindustrial ties to the community.

The importance of community can also be seen in twentieth-century nationalist political movements and, more recently, in efforts to protect or resurrect the rights of indigenous hunting-gathering and agricultural societies in countries such as Brazil. ${ }^{23}$ Both rest on a desire to protect a community and its way of life from the state, other elements of society, or both.

There are also movements demanding full inclusion in civil society for socially-defined "outsiders." In the Western world in recent decades, these have included racial and ethnic minorities, women, and most recently homosexuals. The struggle of lower caste groups in India for social and economic, as well as political, inclusion in society presents an especially striking example of recent movements to overcome invidious definitions of communal membership.

We have identified two key membership rights, the protection of the

22. Barrington Moore Jr., Reflections on the Causes of Human Misery and upon Certain Proposals to Eliminate Them (Boston: Beacon Press, 1970): 2; and Peter Berger, "Are Human Rights Universal," Commentary 64 (September 1977): 62.

23. Marc Pallemaerts, "Development, Conservation and Indigenous Rights in Brazil," Human Rights Quarterly 8 (August 1986), 374-400. See also José R. Martínez Cobo, Study of the Problem of Discrimination Against Indigenous Populations, Volume V: Conclusions, Proposals and Recommendations, UN document E/CN.4/Sub.2/1986/7 and Add. 4. 
TABLE 2

Membership Rights

\begin{tabular}{ll}
\hline \hline \multicolumn{1}{c}{ Right to } & \multicolumn{1}{c}{ Proxy for } \\
\hline FAMILY & Social Security (D22, E9) \\
(D12, D16, E10, C17, C18, C23) & Culture (D27, E15) \\
& Religion (D18, C18) \\
& Minority Culture (C27) \\
& Rights of the Child (C24) \\
& Freedom of Movement (D13, C12) \\
& Education (D26, E13, E14) \\
& Slavery (D4, C8) \\
NONDISCRIMINATION & Legal Recognition (D6, C16) \\
(D1, D2, E2, E3, C2, C3) & Nationality (D15) \\
EQUAL PROTECTION & Religion (D18, C18) \\
(D7, C14, C26) & Minority Culture (C27) \\
& Rights of the Child (C24) \\
& Rights of Aliens (C13) \\
& Debtors Prison (C11) \\
& Political Participation (D21, C25)
\end{tabular}

Note: The source of each right in the International Bill of Human Rights is indicated in parentheses, by article number and document $(D=$ Universal Declaration of Human Rights; $E=$ International Covenant on Economic, Social and Cultural Rights; C = International Covenant on Civil and Political Rights).

family and the prohibition of discrimination, which can serve as proxies for a number of rights enumerated in Table 2.

\section{Family Rights}

Protection of the family is a recurrent theme throughout the International Bill of Human Rights. The Universal Declaration states that "no one shall be subjected to arbitrary interference with his privacy, family home ..." (Article 12), that "men and women of full age . . . have the right to marry and to found a family" (Article 16[1]), and that "the family is the natural and fundamental group unit of society and is entitled to protection by society and the State" (Article 16[3]). The International Covenant on Economic, Social and Cultural Rights declares that "the widest possible protection and assistance should be accorded to the family, which is the natural and fundamental group unit of society" (Article 10[1]), requires special protection for mothers before and after childbirth and for children and young persons (Article 10[2], [3]), and grants special protections to families with respect to education (Article 13[3]). The International Covenant on Civil and Political Rights also prohibits interference with the family (Article 17), guarantees family rights in education (Article 18[4]) and reaffirms the social primacy of 
the family and the right to marry and to found a family (Article 23). The pervasive presence of family rights in these documents is justified not only by the intrinsic importance of the family but by the wide-ranging social and political implications of protecting the institution of the family.

It is important not to romanticize the family: women frequently need protection against abusive husbands and fathers; children often need to be protected against violent, psychologically abusive, or negligent parents or caretakers. Moreover, the very choice of partaking in or refusing family relations is often denied, sometimes violently. In such cases, state intervention to protect victims of familial abuse may be essential.

In a somewhat different vein, many people choose not to live in traditionally recognized family groups and others, such as homosexual couples, find their attempts to establish new forms of households unrecognized by society and the state. Such individuals need to be protected from state attempts to coerce them into traditional family units-or worse, to imprison them for their deviance. We must also remember that in a number of countries the state intervenes not to protect but to undermine the family.

Labor control is one object of state interference with family relations. In South Africa approximately one million female domestic servants are expected to live away from their children, black miners are forced to live in single-sex residences away from families whom they may visit only one month of every year; and countless urban workers are forced by economic necessity, and until 1986 by law as well, to live away from their families. The state creates these conditions in order to ensure a supply of cheap black labor unencumbered by the responsibilities and costs of family ties. ${ }^{24}$ In other states, such as China, family rights are invaded when individuals are assigned to jobs against their will, or without consideration of their family, especially spousal, ties.

A second and increasingly common motive for state interference with family relations is population control. In Europe and North America, politically sensitive family planning issues usually involve decisions of couples or women to prevent conception or refuse to give birth. In many other countries, the issue is whether they are to be permitted to give birth. South Africa encourages birth control for blacks, while discouraging it for whites, and has gone so far as to threaten compulsory sterilization and abortion to reduce nonwhite birth rates. ${ }^{25}$ In India, abusive forced vasectomies, especially among the Muslim population during the Emergency (1975-77), were

24. Jacklyn Cock, Maids and Madams: A Study in in the Politics of Exploitation (Johannesburg: Ravan Press, 1980); Frederick Johnstone, "South Africa," in Donnelly and Howard ed., note 7 above; and Harold Wolpe, "Capitalism and Cheap Labour Power in South Africa: From Segregation to Apartheid," Economy and Society 1 (1972): 425-456.

25. Aziza Seedat, Crippling a Nation: Health in Apartheid South Africa (London: International Defence and Aid Fund for Southern Africa, April 1984): 12-13. 
one reason for Mrs. Gandhi's downfall. ${ }^{26}$ China's one-child campaign has been widely resisted internally and its coercive elements have provoked substantial international criticism. Less well-known is the enforced sterilization, often without anaesthetic, of young girls - some unmarried and childless -in Bangladesh in the 1980s. ${ }^{27}$

The issue of overpopulation is indeed a difficult one. With different social arrangements, all of the world's five billion people could be fed. ${ }^{28}$ But new social arrangements are not likely to emerge in the short or medium run. Meanwhile, in many countries that do not presently meet their people's basic needs, population growth far outstrips economic growth. In almost all less developed countries, reduced population growth rates could contribute significantly to increased per capita incomes, and thus, make available more resources that might be used for satisfying basic human needs.

Family planning, however, need not be rights-abusive. Information and contraceptives usually can be used instead of coercive, invasive, and even physically dangerous methods of population control such as forced abortions or sterilization. Social security provisions can both protect, and limit the size of, families. Old age pensions, for example, lessen the necessity of having large numbers of children to ensure support for their parents. Educating girls reduces the risk of early pregnancy. Child welfare provisions and health care improvements that ensure higher survival rates for infants also tend to lower the birth rate. Protection of the family, protection of the child, and population reduction usually can be made to coincide. ${ }^{29}$

A third, and perhaps most important, reason for the state's interference with family relations is that it can operate as part of a broader effort to subvert private social relations, which may provide a basis of loyalty to groups and institutions other than the state. The family is the seat of socialization. A child absorbs values and customs primarily from the family, and with the family participates in those religious and ethnic rituals that it later comes to value as an adult, contributing to his or her sense of dignity and belonging. Totalitarian states in particular try to break down all competing loyalties that individuals might hold, creating anomic citizens whose only - and therefore easily manipulable-sense of connection to the community is through state created and state controlled institutions, such as party youth leagues. For example, in the Soviet Union, children are sometimes removed from Christian families that "proselytize" them, ${ }^{30}$ not to protect children from indoc-

26. Barnett R. Rubin, "India," in Donnelly and Howard ed., note 7 above. For a fictionalized account of this episode, see Salman Rushdie, Midnight's Children (New York: Knopf, 1981).

27. James C. Seymour, "China," in Donnelly and Howard ed., note 7 above; and Shelley Feldman, "Women in Bangladesh," paper presented at a conference on human rights in Asia, State University of New York at Buffalo, March 1987.

28. See note 14 above.

29. Independent [Brandt] Commission, note 14 above, pp. 106-108.

30. Kowalewski, note 12 above. 
trination into false or reactionary beliefs, but to secure the state's place as the only agent or their socialization.

The possibility of this type of state interference with family relations necessitates protection of the rights to culture, religion, and minority culture, respect for which can be assessed to a considerable extent by the level of respect for family rights. No less important is the liberty of families to choose their children's schools. This right is sometimes exercised in ways that reinforce class privilege (e.g., "public" schools in England), ethnic bias (e.g., pressure for "all Dutch" schools in Holland ${ }^{31}$ ), or racial exclusion (e.g., "Christian academies" in the American South) and thus may undermine equality and nondiscrimination. Nevertheless, to argue that there is no need to protect the right of families to choose their children's schools is to make the unrealistic assumption that states can always be relied on to provide nondiscriminatory, equal and ethically acceptable education. The right to choose one's children's schools is the right not to be required to submit one's children to political and ethical socialization by the state. It is also the right to preserve one's culture, religion, and language by having one's children educated in schools that share these aspects on one's way of life.

Probably the worst invasion of family rights in the practice of spying on families. Under Nazism, children were taught in schools to inform against their own parents, as were children in Stalinist Russia. In communist systems, such as Cuba, neighborhood Party units are often expected to provide the state with information concerning families included in such units. This method of spying was common, and effective, in China during the Cultural Revolution. ${ }^{32}$

The effective preservation of family rights, therefore, is closely associated with the preservation of the right to privacy; of the right of families to preserve their ethnic customs, religion, and language; and of the rights of women, children, and others who are specially protected by social security measures (See Table 2). A state that respects the family must also protect a wide range of related social rights.

In many states, however, families of a certain ethnic group or social status may be well protected, while others are denied protection on the basis of ascriptive criteria. In Japan, for example, ethnic Koreans and the descendants of those held jobs once considered defiling (such as butchers), suffer both legal and social discrimination. ${ }^{33}$

31. We owe this example to Peter Baehr.

32. Robert Conquest, Harvest of Despair (Edmonton: University of Alberta Press, 1986); Rhoda Rabkin, "Cuba," in Donnelly and Howard ed., note 7 above; and Liang Heng and Judith Shapiro, Son of the Revolution (New York: Knopf, 1983).

33. Lawrence Beer, "Japan," in Donnelly and Howard ed., note 7 above, 219; and Yuji Iwasawa, "Legal Treatment of Koreans in Japan: The Impact of International Human Rights Law on Japanese Law," Human Rights Quarterly 8 (May 1986): 131-197. 
Moreover, while the family may be "the natural and fundamental group unit of society," it is only a part of society, and it is only in the context of society as a whole that a life of dignity is possible. The prerequisite for social participation is recognition of one's membership in society as an individual, regardless of, as well as respectful of, one's family allegiances. Thus, the right to family must be supplemented by the right to nondiscrimination.

\section{Nondiscrimination}

There are two aspects of the right to nondiscrimination. Article 2 of the Universal Declaration and Article 2 of both Covenants recognize that individuals are entitled to enjoy all enumerated rights on an equal basis and "without distinction of any kind, such as race, color, sex, language, religion, political or other opinion, national or social origin, property, birth or other status." In addition, both Article 7 of the Declaration and Article 26 of the Covenant on Civil and Political Rights state that "all persons are equal before the law and are entitled without any discrimination to the equal protection of the law." Both the general principle of the equal enjoyment of all rights and the special legal principle of equal protection support the conclusion that from a human rights perspective, human dignity is fully respected only where individuals are treated as fully equal members of society.

Race, color, and sex are accidents of birth, ascribed criteria over which the individual has no control. Religion is also frequently considered to be given to a child at birth, although changes in religion are commonplace. The principle underlying prohibitions of discrimination on such grounds is clear: the moral worth of human beings is not in any way connected with such natural accidents; no one should suffer for characteristics over which he or she has no control. Social status ascribed at birth, which likewise rests on circumstances beyond the individual's control, is also prohibited grounds for discrimination. For example, victims of India's caste system-those at the very bottom who are still socially, although not legally, viewed as "untouchables" - should be protected from discrimination. ${ }^{34}$

Protecting full membership in society for all, however, also requires prohibiting discrimination on the grounds of certain acquired characteristics. For example, political opinions and property are at least partially under the individual's control. The Covenants' prohibition of nondiscrimination on these grounds is an assertion that individuals are fully and equally entitled to enjoy all human rights regardless of the choices they make concerning these important aspects of their lives. There is an irreducible minimum of

34. Rubin, note 26 above; and Jack Donnelly, "Traditional Values Versus Universal Human Rights: Caste in India," paper presented at a conference on human rights in Asia, State University of New York at Buffalo, March 1987. 
respect to which one is entitled, including in particular the full and equal enjoyment of all human rights, regardless of decisions one makes in these specified areas of protected choice.

The right not to be discriminated against on the basis of property - which sets the context for Article 11 of the Covenant on Civil and Political Rights, stating that "No one shall be imprisoned merely on the ground of inability to fulfill a contractual obligation" (prohibition of debtors' prisons)-is particularly interesting in this regard. Taken seriously, this provision would protect not only persons of real or alleged "bourgeois" origin in radically communist regimes, but also the poor in all societies. Its point is that one's human dignity, one's intrinsic worth as a person, supersedes the law of contract or normative evaluations of the individual's responsibility to take the consequences of his or her own actions. Even if the poor are poor as a result of their own activities, they remain equally entitled to enjoy all human rights; even if perfect equality of opportunity existed, those who failed to take advantage of the opportunities available to them would still be protected from discrimination on the basis on property.

Furthermore, the principle of nondiscrimination prohibits such practices as "pawning" (giving oneself or a relative to another person for a certain period of time in payment of a debt), which occurs in some African societies, or debt peonage or bonded labor, which persists in India. A person should not be treated as a piece of property, even for a limited period of time, as a consequence of economic misfortune, or even improvidence. ${ }^{35}$

As indicated in Table 2, the right to nondiscrimination can stand for a variety of other rights as well. A state properly abiding by the principles of nondiscrimination and equal protection almost certainly will also protect the right to legal recognition and the right not to be held in slavery. Assuming that political participation is permitted, it will also protect the right to participate in political activities and to seek and hold office on a nondiscriminatory basis. A policy of nondiscrimination, along with effective protections of the right to a family, should also protect the rights of children, who would have rights commensurate with their status as minors. In conjunction with

35. Banning discrimination on the basis of acquired characteristics widens the scope of political action in pursuit of rights, and suggests the need to extend the list of prohibited grounds in Article 2 of the Covenants. The gay liberation movement, for example, is not completely analogous to the civil rights or women's movements, which are pursuing equal rights for persons suffering discrimination on the basis of biological birth characteristics over which they have no control. Although homosexuality seems to be at least in part the result of hereditary or environmental factors beyond the individual's control, many opponents of equal rights for homosexuals still assume that sexual preference is a matter of personal choice, and some gay activists, especially in the lesbian rights movement, agree that choice is involved. But even if homosexuality were demonstrated to be an acquired (chosen) rather than ascribed (uncontrollable) characteristic, the precedents noted above suggest that it should not be the basis for discrimination-even if the choice deeply offends large sectors of the population and traditional community values. 
TABLE 3

Protection Rights

\begin{tabular}{ll}
\hline \hline \multicolumn{1}{c}{ Right to } & \multicolumn{1}{c}{ Proxy for } \\
\hline HABEAS CORPUS (D9, C9) & Torture (D5, C7) \\
& Arbitrary Arrest (D9, C9) \\
& Ex Post Facto Laws (D11, C15) \\
& Presumption of Innocence (D11, C14) \\
& Rights of Detainees (C10) \\
& Political Participation (D21, C25) \\
& Torture (D5, C7) \\
INDEPENDENT JUDICIARY & Legal Remedy (D8, C2) \\
(D10, C14) & Access to Courts (D10, C14) \\
& Political Participation (D21, C25) \\
\hline
\end{tabular}

Note: The source of each right in the International Bill of Human Rights is indicated in parentheses, by article number and document $(\mathrm{D}=$ Universal Declaration of Human Rights; $\mathrm{E}=$ International Covenant on Economic, Social and Cultural Rights; $\mathrm{C}=$ International Covenant on Civil and Political Rights).

the protection of family, and freedom of the press and association, a policy of nondiscrimination would protect the right to practice one's own religion and preserve one's culture. Furthermore, if the prohibition against discrimination on the basis of property were taken seriously, it would serve as a further protection of the right to food and adequate health care. It might also ensure that if discriminatory laws and practices against, for example, blacks in South Africa or the United States, were ended, previously existing forms of racial discrimination could not simply be transformed into a new class discrimination with a substantial racial overlap.

\section{PROTECTION RIGHTS}

Even if a state were to protect survival rights and guarantee to all full rights of membership in society, individuals might still be subject to a wide range of abuses by the state, including arbitrary arrest and detention and prosecution under ex post facto laws, so long as such practices did not reflect invidious discrimination. A life of dignity thus requires the observance of what we have termed "protection" rights. They might also be called legal or judicial rights, for their principal thrust is to establish the rule of law and to provide judicial review of governmental action.

We contend that the rights to habeas corpus and an independent judiciary serve as indicators for this fairly diverse set of rights. As these rights are familiar and relatively uncontroversial, our exposition will be brief. Since they are closely connected, representing two sides of the process of judicial review, they will be discussed together.

Article 9 of the Universal Declaration, in its entirety, reads "No one 
shall be subjected to arbitrary arrest, detention or exile." Article 9 of the International Covenant on Civil and Political Rights adds, among other provisions, the rights to be informed of the charges when arrested, to challenge the lawfulness of any detention and receive compensation for unlawful arrest or detention, to be released from custody while awaiting trial, and to be brought before a judge and tried "within a reasonable time" or be released.

The right of habeas corpus, which requires the state to bring detainees before a judge or court to determine the lawfulness of their detention, lies at the heart of these protections, ${ }^{36}$ which seek to ensure that the criminal law does not become an arbitrary instrument of oppression in the hands of the state, especially the executive. To ensure that the writ of habeas corpus is not just a formality, judges must have the power to order the release of prisoners; it is not sufficient, as is provided for in most Preventive Detention Acts in English-speaking Africa, that they merely "advise" the President about the legitimacy of detention. ${ }^{37}$ Moreover, judicial review of detentions must also be used to enforce the requirement of a speedy trial, to prevent anyone from languishing in detention merely at the behest of the executive agencies of the state.

To assure procedural regularity, even by the right to habeas corpus, the judiciary must be independent and effective. The judge to whom detentions must be justified must be an officer of the law, not a dependent agent of those whose behavior he or she is required to review. As Article 14 of the Covenant on Civil and Political Rights puts it, "everyone shall be entitled to a fair and public hearing by a competent, independent and impartial tribunal established by law." Article 10 of the Universal Declaration uses almost the same words. In Anglo-American political thought, this principle has usually been expressed in terms of the separation of powers; in the United States, the language of checks and balances is also regularly used.

The need for protection rights arises from the paradoxical relation of the state to the enjoyment of human rights. The state is indispensible to the effective implementation of all human rights, as we have seen in some detail with respect to those rights discussed above. The concentration of power required to assure such protection, however, poses perhaps the greatest threat to those rights. Since the state cannot be eliminated without disastrous human rights consequences, it must be controlled.

Part of that control must come from outside the government, from "society." Such "external" control in the form of empowerment rights, is discussed below. But there must also be "internal" checks on governmental

36. Habeas corpus is a distinctly Anglo-American practice. There are, however, roughly analogous provisions in many other legal systems. We use "habeas corpus" here not in the strictest technical sense of the term but rather as a convenient verbal shorthand for "the right to protection against arbitrary arrest or detention."

37. Rhoda E. Howard, Human Rights in Commonwealth Africa (Totowa, NJ: Rowman and Littlefield, 1986): 152-159. 
power that are built into the day-to-day operation of the state. These are provided by what we call protection rights.

The most effective internal checks require the separation of the functions and powers of government and the conferral of independence on the courts so that they may watch over and review the actions of other branches of the government. If such internal controls are to be effective, the judiciary must be a genuinely independent branch of government, a point underscored by the attacks on the courts conducted in most newly established repressive regimes, such as Marcos' assault on the judiciary during the consolidation of martial law in the Philippines. ${ }^{38}$

The preservation of human rights, however, requires that courts have the ability to do more than form independent judgments of whether or not there has been an infraction of the law. Unless a judiciary has the power to overrule the actions of the executive on substantive, as well as procedural, grounds-for example, the power to interpret and apply the constitution in order to overturn rights-abusive statutes - its independence will be of little value in the long run, especially in the face of a careful and committed repressive regime. Without such powers of substantive review of law, policy, and practice, even the most dedicated and independent of judges can act only against arbitrary or careless violations of human rights.

For example, the South African judiciary has a long tradition of integrity and independence, but during the course of Nationalist rule its influence over policy and practice has been steadily diminished through legislation that legalizes mass and flagrant violations of most human rights. So long as the government is relatively punctilious, it can circumvent effective judicial control. In the summer of 1986, to cite but one of many instances, the courts overturned key emergency legislation, but the government simply redrafted the measures so as to avoid their earlier technical errors. Similarly, judges are powerless to prevent - in fact, are required to approve-"judicial" executions (murders) of ordinary citizens and human rights activists.

Likewise, one of the distinctive features of Soviet rule after Stalin has been the institutionalization of repression through law. As in South Africa, violations of human rights occur less often as the result of procedural irregularities than as an effect of substantive law. Nearly all dissidents in prison or in exile have been tried and convicted, by the book, of violating duly promulgated laws. It is the laws themselves that are abusive of human rights.

We contend that the power of substantive review is implicit in the requirement that courts be impartial and independent. The judiciary must be able to rule on the human rights consequences of any legislation. Nonetheless, the power of substantive review is not a part of most legal systems (it

38. Claude, note 9 above. 
exists only to a limited extent even in Britain and France), and it is not explicitly required by either the Universal Declaration or the Covenants. Furthermore, the principal remedy for laws that are violative of human rights, even in a system whose judiciary possesses the greatest powers of judicial review, lies not in the internal checks provided by protection rights, but in the external checks that we have termed "empowerment rights." These are discussed in the following section.

The limited scope of protection rights, however, should not obscure their fundamental importance. In fact, it underscores the essential theoretical point that the protection afforded by the recognition of any human right or group of rights, no matter how important, is severely limited in the absence of safeguards for related and equally fundamental rights. Thus, we insist that all human rights are inherently interdependent and indivisible.

The protection rights of habeas corpus and judicial review are good proxies for a variety of other legal or civil rights, noted in Table 3 above. The principle of the rule of law prohibits the use of ex post facto laws. Together, habeas corpus and an independent judiciary go a long way toward assuring the availability of legal remedies for violations of rights; an independent judiciary in particular is a necessary (although not sufficient) condition for the existence of effective remedies against governmental infringements of rights. Habeas corpus and judicial review are also essential mechanisms for action against torture and other violations of the rights of those subject to detention. Furthermore, we are aware of no legal system where habeas corpus and an independent judiciary are well established but the presumption of innocence is not generally secured; in practice, governments that widely presume the guilt of those they detain also infringe upon judicial independence or deny habeas corpus.

We must also note the potential contribution of these protection rights to the assurance of all the other key rights that we have identified. Without protection rights, no other rights are secure against infringement by the modern state; without the internal checks they provide, the enjoyment of other rights rests on little more than good faith of the government and whatever external constraints it might face.

Protection rights have a particularly important role in safeguarding the right to political participation. Persons involved in political activity directed against, or not approved by, the government are likely to be the principal targets of the kinds of abuse of governmental power that protection rights seek to prevent or overturn. By protecting the government's political opponents against most arbitrary abuses of state power, protection rights can contribute greatly to the creation of a public space for political action. ${ }^{39}$

39. Compare Richard Kiwanuka, "On the Paucity of Human Rights NGOs in Africa," Human Rights Internet Reporter 11 (November 1986): 11. 


\section{EMPOWERMENT RIGHTS}

What is lacking so far in our account is any sense of people as active, creative beings in charge of, or at least struggling to shape, their lives. People must not simply be protected against attacks by the state or other citizens, they must be empowered to act and to lead autonomous lives. All the rights previously discussed are principally passive protections; the individual is the beneficiary of the right, but not the central actor in the struggle to realize human rights. This central role for the individual is provided only by empowerment rights. And without positive empowerment, even the rights discussed above are likely to be precarious.

Empowerment rights provide what we referred to above as "external" checks on state power. The internal checks of protection rights only assure that irregular procedures are not used against individuals or groups by the state. Unless individuals, separately and collectively, are able to shape these procedures - to set the rules of the game, and not merely be assured that the rules are applied as written-oppression is still a very real possibility, as is clearly illustrated in the examples above of the Soviet Union and South Africa.

We argue that the three central empowerment rights are the rights to education, freedom of the press, and freedom of association. The key to social action in defense of rights, in our view, is an educated citizenry, able

\begin{tabular}{cl}
\hline & \multicolumn{1}{c}{$\begin{array}{c}\text { TABLE 4 } \\
\text { Empowerment Rights }\end{array}$} \\
\hline \hline \multicolumn{1}{c}{ Right to } & \multicolumn{1}{c}{ Proxy for } \\
\hline EDUCATION (D26, E13, E14) & Culture (D27, E15) \\
& Minority Culture (C27) \\
& Thought, Conscience, Religion (D18, C18) \\
& Freedom of Opinion (D19, C19) \\
& Political Participation (D21, C25) \\
& Thought, Conscience, Religion (D18, C18) \\
& Freedom of Opinion (D19, C19) \\
FREE PRESS (D19, C19) & Political Participation (D21, C25) \\
& Free Trade Unions (D23, E8, C22) \\
FREEDOM OF ASSOCIATION & Social Security (D22, E9) \\
(D20, C22) & Work (D23, D24, E6, E7) \\
& Assembly (D20, C21) \\
Thought, Conscience, Religion (D18, C18) & Freedom of Opinion (D19, C19) \\
& Political Participation (D21, C25) \\
\hline
\end{tabular}

Note: The source of each right in the International Bill of Human Rights is indicated in parentheses, by article number and document $(D=$ Universal Declaration of Human Rights; $E=$ International Covenant on Economic, Social and Cultural Rights; C = International Covenant on Civil and Political Rights). 
to spread its ideas and to organize in defense of its rights. ${ }^{40}$ We do not include a separate right to take part in government or public affairs, for reasons discussed at the conclusion of this section.

\section{The Right to Education}

Article 26 of the Universal Declaration and Article 13 of the International Covenant on Economic, Social and Cultural Rights recognize the right of everyone to education, including free and compulsory primary education and access to secondary, technical, and higher education on the basis of merit and, to the extent possible, without cost to the student. The right to attend schools not run by the state is also recognized.

Empowerment rights are concerned principally with the goals of personal autonomy and efficacy; they allow the individual to determine the shape and direction of his or her life. Education provides much of the basic intellectual capacity that enables the individual to think seriously and critically about what it means to live a good life; to examine and appraise actions, institutions and ideas; and to choose a course of action on the basis of such appraisals.

Schools are often used as an instrument of social control rather than personal liberation, as a mechanism to enforce intellectual conformity rather than foster creativity and autonomy. Nonetheless, there is the potential for subversion in even highly coercive and controlled systems of education, as is illustrated by the disproportionate representation of the relatively well educated among political dissidents in North, South, East, and West alike. No matter how controlled the curriculum, the skills developed in educational institutions can be applied to the development of ideas other than those sanctioned by the state.

Beyond the liberating potential of education, we have chosen the right to education as a key measure of national human rights performance because of its links to other empowerment rights. Freedom of the press, and the political empowerment for which it stands, is made far more significant by education; education creates an audience capable of being informed and mobilized and is absolutely essential to those who would write. Education similarly magnifies the possibilities for and the impact of trade unions and other associations. We will return to these points below.

The right to education can be crucial to creating a private space for intellectual autonomy, especially where schools not controlled by the state are easily accessible. As discussed above, the potential for education to be

40. Compare Robert Justin Goldstein, Political Repression in 19th Century Europe (Beckenham, Kent: Croom Helm, 1983); and David P. Forsythe, Human Rights and World Politics (Lincoln: University of Nebraska Press, 1983): 35-36. 
used in criticism of the state can be greatly enhanced when education is under the control of the family. Conversely, education can be a way to strengthen and protect membership rights. This mutual reinforcement is characteristic of all the empowerment rights.

At minimum, the right to education would guarantee to all access to the skills and knowledge needed for full membership in society. For example, in the contemporary world one cannot fully participate in society (or the types of participation available are seriously restricted) if one is illiterate. More broadly, one's options are limited if one does not have access to the cultural models, forms, examples, and information of the society: for example, the accent and idiom, the cultural and historical points of reference, and the norms of civility of the dominant or mainstream groups in society. ${ }^{41}$ In modern and modernizing societies, formal education is usually the standard way to acquire such essential skills and information.

Education also increases one's opportunities to take part in the cultural life of a society, and to enjoy the benefits of scientific progress, important rights recognized in Article 15 of the International Covenant on Economic, Social and Cultural Rights. In fact, the link between education and these cultural rights is so close that we would argue that in most instances the right to education, combined with family rights and the right to nondiscrimination, provides a reliable indicator of their status.

Education can also make important contributions to social mobility and thus to combatting class-based discrimination. In developing countries there is substantial evidence to show that even basic literacy contributes substantially to an individual's integration into a modern economy and to his or her ability to take advantage of the opportunities it offers. ${ }^{42}$ And in almost all countries, education is one of the few ways for a poor child to move rapidly up the social ladder. This is true even in countries with strong class or status hierarchies; even taking into account problems of differential access, education is likely to be one of the few resources available that will allow one to break into or through the hierarchy.

Finally, education can be important even to the protection of survival rights. An effective health care system requires that people be aware of public health dangers. Disseminating information, for example, on methods for treating or avoiding parasite-infested water, is much easier and cheaper if the public is literate. Similarly, technical improvements in agricultural methods, which can increase food production, are more easily disseminated to the literate. As Frances Steward puts it, "education is an important factor in determining [basic needs satisfaction] at all income levels."

41. See, for example, Richard Rodriguez, Hunger of Memory: The Education of Richard Rodriguez (Boston: D. R. Godine, 1983).

42. Christopher Colclough, "The Impact of Primary Schooling on Economic Development: A Review of the Evidence," World Development 10 (March 1982): 167-186.

43. Frances Steward, Basic Needs in Developing Countries (Baltimore: Johns Hopkins University Press, 1985): 96. 


\section{Freedom of the Press}

Articles 18 and 19 of the Universal Declaration, which are closely paralleled by the same articles of the Covenant on Civil and Political Rights, recognize a cluster of rights that we will argue can be largely subsumed under the right to freedom of the press.

Everyone has the right to freedom of thought, conscience and religion; this right includes freedom to change his religion or belief, and freedom, either alone or in community with others and in public or private, to manifest his religion or belief in teaching, practice, worship and observance.

Everyone has the right to freedom of opinion and expression; this right includes freedom to hold opinions without interference and to seek, receive and impart information and ideas through any media and regardless of frontiers.

These rights give considerable substance to the abstract idea of intellectual autonomy discussed above. One may think whatever one wants. One may hold whatever opinion one wants. And one may freely express one's thoughts, opinions, and beliefs. Furthermore, one is free to manifest his or her religious beliefs individually and collectively, both in private and in public.

As we noted above, education helps to give force and practical meaning to these freedoms by providing resources with which one may form or develop, rather than just receive, beliefs and opinions. The freedoms of thought, conscience, religion, belief, and opinion protect the fruits of intellectual autonomy, which is the goal of the right to education. And the right to a free press, understood broadly as a right to freedom of expression through any medium, allows one to begin to act on these beliefs. Words, expressed in public, often are the first step towards deeds. Thus, we would argue that the rights to freedom of conscience, religion, belief, and opinion can largely be subsumed under the right to education, insofar as they represent intellectual empowerment, and under the rights to a free press and freedom of association, insofar as they represent political empowerment.

Freedom of the press ${ }^{44}$ allows one to advocate one's ideas and thus attempt to see them realized. Freedom of expression is of little value if those who wish to express their ideas are denied access to either publicly or privately owned channels of communication. There is no real freedom of expression if one is prevented from speaking to one's target audience, or at least those who wish to hear; those without access to the media are not really free to express their views. Similarly, those who are denied access to

44. Our concentration on the press, and thus on public speech to the general neglect of private speech, can be further justified by the fact that we are aware of no government that allows public expression of beliefs or opinions but controls the private expression of those beliefs or opinions (although many do allow private expressions that are prohibited or severely controlled in public). 
the views of others do not really enjoy the freedom to hold opinions without interference.

Clearly, then, a free press is also crucial to the right to political participation. In particular, a free press is essential to effective political action aimed at effecting changes in government or its policies. Whether that action involves electoral politics or helps to put pressure on decision-makers with respect to a particular policy or decision, the closing of the media precludes virtually all but a small elite with direct access to the government from having a significant political impact.

Finally, freedom of the press can be crucial to ensuring respect for all other rights: by publicizing actions of the state it helps to mobilize advocates of change. Violations of human rights are less likely to occur or to continue if they can be effectively publicized, and less likely to begin if the violator knows that his actions may become widely known. This is especially true where state action is subject to review by an independent judiciary. Conversely, even an independent judiciary is likely to be hamstrung where the flow of information is tightly controlled. We also note that responsible governments are likely to find a free press an invaluable source of information about popular views of their policies.

\section{Freedom of Association}

The right to freedom of association, recognized in Article 20 of the Universal Declaration and Article 22 of the Covenant on Civil and Political Rights, entails the right to form associations; to formulate association policies and make them known; and to use legitimate tactics such as public assembly, recourse to the press, and the formation of political parties to exert pressure upon the state to adopt particular policies. Thus, under freedom of association, we group the rights to free trade unions, freedom of assembly, and political associations such as political parties (although a right to form political parties is not explicitly mentioned in either the Universal Declaration or the Covenants).

In the industrialized world, free trade unions are perhaps the most important manifestation of the right to freedom of association. Union activities on behalf of workers' interests are often essential to the effective protection of economic rights. But trade unions perform an equally important political function, through direct participation in the electoral process (e.g., the Trade Union Congress' central role in the British Labour Party), indirect but regular political linkages (e.g., the close association between many liberal Democrats and the AFL-CIO in the United States), and as an organized social force outside of government, a role that was especially important in nineteenth and early twentieth century Europe in bringing about the rise of the welfare 
state. The potential political power of organized labor is underscored by the extensive repression of workers' organizations in the United States and Canada well into the twentieth century, ${ }^{45}$ and in the Soviet bloc right up to the present, as the example of Solidarity so vividly indicates.

In the nonindustrialized world as well, trade unions are increasingly important political organizations, despite the fact that many are incorporated into state structures, as in, for example, Mexico or Tanzania. ${ }^{46}$ Literate, centralized, and organizationally crucial workers in primary industries and services can bring entire economies to a standstill, even in countries where 85 percent of the population still lives off the land.

In addition to trade unions, peasants' unions and other free economic associations have a key role to play in the nonindustrialized world, even though their organization is much more difficult, given the dispersed nature of peasant populations and the lower rates of literacy among rural peoples. During the short political thaw in China in 1978 through 1979, peasants from isolated, extremely poverty-stricken hinterland areas suddenly appeared in the capital demanding to be heard. The speed of the crackdown against them and other politically active groups, especially students, revealed the government's fear of real protest. ${ }^{47}$ Similarly, literate peasants in Guatemala have been special targets of government terror. ${ }^{48}$

The political, at times even revolutionary, potential of organizations formed initially to effect economic change not only underscores the artificiality of the distinction between economics and politics, but indicates that political empowerment is implicit in the right to freedom of association. Freedom of association protects any voluntary organization that mediates between citizen and state, and thus helps to insulate individuals from the power of the state. More importantly, people acting in concert have more strength to resist state action than individuals acting alone, even in great number.

Human rights are protected in practice in state societies only through the constant political involvement of a large number of groups, most of which are concerned only with particular rights and interests pertinent to their own situations. These include communal or ethnic organizations, such

45. Robert Justin Goldstein, Political Repression in Modern America from 1870 to the Present (Cambridge, MA: Schenkman, 1978), chap. 1; and Thomas Berger, Fragile Freedoms: Human Rights and Dissent in Canada (Toronto: Clarke, Irwin, 1982): chap. 5.

46. Peter Worsley, The Three Worlds: Culture and World Development (Chicago: University of Chicago Press, 1984): 226-27; and Rhoda E. Howard, "Third World Trade Unions as Agencies of Human Rights: The Case of Commonwealth Africa," in Trade Unions and the New Industrialization of the Third World, ed. Roger Southall (London: Zed Press, 1988).

47. Liang Heng and Judith Shapiro, After the Nightmare: A Survivor of the Cultural Revolution Reports on China Today (New York: Knopf, 1986).

48. Bowen, note 10 above. 
as caste associations in India; religious institutions and organizations, and "base communities" and other groups associated with "liberation theology" in Latin America; women's groups; and other groups. Most associations act on behalf of limited constituencies. But together they have a common interest in freedom of association, and through that, political participation. A state that protects freedom of association, therefore, protects the right of many diverse groups of citizens to enter and influence the political arena.

Freedom of association is a good proxy not only for the right to political participation, but also for the right to work, which we understand as not merely the right to earn a wage, but the ability to choose and to influence the conditions of one's labor. In our view, the right to work requires freedom of association for workers. In the Soviet Union, for example, jobs are officially guaranteed, but in practice they are contingent on political conformity: political dissidents, unauthorized artists, musicians and writers, Jews seeking to emigrate, and evangelical Christians are regularly deprived of professional positions and assigned to menial tasks-or worse; the right to work for some Soviets means only the right to toil in slave labor camps.

The right to work should be the right to find satisfying work, under conditions that are not intrinsically uncomfortable, displeasing, or exploitative, not merely the right to labor for a wage. The right to work ought to include the right to make use of one's creative capacities, not merely the right to supply labor power to the endeavors of others. But workers tend to be regarded merely as human capital, exploitable and reducible to their intellectual and/or muscular capacities, unless they have free trade unions to defend their interests - which brings us back to the political dimensions of freedom of association. The right to work may protect one and one's family against economic deprivation; if satisfying work is available, it may even contribute to a sense of personal worth and achievement. But without a right to organize in order to shape the conditions and terms of labor, and ultimately the socioeconomic structure of society, it is inadequate.

Freedom of association is also a good proxy for several other rights, as indicated in Table 4. Governments which permit free and politically active trade unions, as well as other types of organizations, are more likely to grant social security rights. For example, in nineteenth century Europe, welfare rights were obtained only after workers had the legal and real capacity to organize. ${ }^{49}$ Freedom of assembly consists largely of the right to associate, on a regular or irregular basis, in public. Public demonstrations can have a powerful political impact, as illustrated by the Philippines in 1986 and South Korea in 1987. And, like freedom of the press, one of the principal uses of the freedom of association is likely to be to support and defend the freedoms of thought, conscience, religion, and opinion.

49. Goldstein, note 39 above. 


\section{Political Participation and Multiparty Systems}

Perhaps the most controversial aspect of our short list of rights is the absence of the right to political participation, or, as Article 21 of the Universal Declaration puts it, "the right to take part in the government of his country, directly or through freely chosen representatives." The right to electoral participation in particular is explicitly included in Article 21 of the Universal Declaration and Article 25 of the Covenant on Civil and Political Rights. Nonetheless, despite our emphasis on empowerment rights, we have not included political participation as a key right, both because of the extreme ideological controversy over the meaning of this right and because it is likely to be redundant if the rights to a free press and freedom of association, along with the protection rights to habeas corpus and an independent judiciary, are respected. We contend that the substance of the right to political participation is better encompassed by the four protection and empowerment rights identified above than by the vague, controversial, and relatively easily abused notion of "free elections," or, as the Covenant puts it, "genuine periodic elections."

What is a "free" or "genuine" election? Consider the following cases. In El Salvador in 1985 all citizens were required to vote in a fairly open contest between the center and the right, but with the principal leftist party excluded by law. Abstention, however, was likely to be considered by the police, the military, or the death squads to be a sign of disloyalty. In Nicaragua at roughly the same time the parties of the right chose to boycott the election, but opposition parties that did participate were able to garner roughly a third of the vote. ${ }^{50}$ In most of the Soviet bloc countries, voting is compulsory and voters are asked simply to approve party-selected candidates. In Kenya during the 1970s, despite a de facto one party political system, significant numbers of unpopular incumbents were turned out of office. ${ }^{51}$ In the United States today, elections are completely free but in practice one has a choice between center and center-right parties; there is no viable leftist or even socialdemocratic, option. In Senegal in the late seventies, voters were offered choices among candidates from three, but only three, state-sanctioned parties, which were required by law to represent particular ideological viewpoints. ${ }^{52}$ In the Philippines, all elected Presidents, including Corazon Aquino, have come from two families. ${ }^{53}$

All of these elections have been called free and genuine by their supporters and shams by their detractors - and there is at least a kernel of truth

50. Liisa Lukkari North, "El Salvador," in Donnelly and Howard ed., note 7 above; and Gander, note 19 above.

51. Howard, note 36 above, 139.

52. Martin Klein, "Senegal," in Donnelly and Howard ed., note 7 above.

53. Claude, note 9 above. 
in each characterization. Therefore, given the seemingly unavoidable controversy surrounding the definition of "genuine periodic elections" in the contemporary world, and the feasibility of effectively protecting the right to political participation through protection of the rights to habeas corpus, a free press, freedom of association, and the preservation of an independent judiciary, we do not include in our short list a separate right to electoral participation.

A brief comment on the right to multiparty elections is probably in order, though, given the emphasis placed on this right by well-known organizations such as Freedom House, and by many other groups in the West, particularly those on the political right. It is important to note that neither the Universal Declaration nor the Covenants include or even imply a right to multiparty elections. There is also a serious danger of rigid formalism in relying on such a measure of political rights and participation.

We agree that, all other things being equal, an open, multiparty, competitive system allows for more genuine political participation than a no party or a one party system. Likewise, a multiparty system in which no parties are excluded from participating allows for more genuine political participation than one in which some are excluded by law. In a multiparty system, it is possible for voters to oust the government and substitute a new set of leaders. In a one party system, even one which allows a genuine choice of candidates, replacement of the government is not possible.

Nevertheless, one party systems can allow for greater or lesser degrees of political participation. Ideological conformity may be either required or irrelevant; candidates for office may be nominated either from above or by local committees; there may be several candidates, or only one, for the office of president. ${ }^{54}$ Mexico is a good example of a de facto one party state in which opponents and the interests they represent are usually (although not always) coopted into the party, which is defined less in ideological than organizational terms. The relatively open or closed nature of an official ruling party in a noncompetitive system must be considered in any serious evaluation of the extent of political participation.

Moreover, real multiparty political competition is not possible without the prior establishment of other rights. This is especially relevant to the evaluation of the human rights records of newly emerging Third World states. In Uganda, for example, the central human rights objective is to restore the most basic right of life. It may be that the only successful way to do this, in a severely fragmented society, is through the formation of a single ruling party incorporating elements from all regional and ethnic groups. The presence of competitive political parties can be a mere cover for intra-elite factional infighting in societies in which the majority of the people are still

54. Howard, note 36 above, 140-144. 
TABLE 5

Other Rights
A. International Order
ALIENS (C13)
ASYLUM (D14)
MOVEMENT (D13, C12)
NATIONALITY (D15)
INTERNATIONAL ORDER (D28)
B. Property
PROPERTY (D17)
C. Self-Determination
SELF-DETERMINATION (E1, C1)

Note: The source of each right in the International Bill of Human Rights is indicated in parentheses, by article number and document $(D=$ Universal Declaration of Human Rights; $E=$ International Covenant on Economic, Social and Cultural Rights; C = International Covenant on Civil and Political Rights).

illiterate and disorganized and perceive politics mainly as patron-client relations. Nigerian regional politics is a case in point.

The formal existence of multiple political parties in and of itself does not assure effective implementation of the right to political participation. Thus, both for reasons of economy and in order to avoid interpretative controversies of a sort that attach to none of our other key rights, we close our list of rights at ten and exclude the right to a multiparty political system.

\section{OTHER AND ANOMALOUS RIGHTS}

We have subsumed most of the major rights in the International Bill of Human Rights under the ten rights discussed above. Nonetheless, a few remain unaccounted for, either in whole or in part. These fall into three groups: a set of five rights pertaining to nonnationals within the structure of international society; the right to property; and the right of peoples to self-determination. These rights also seem to have proved troublesome for the drafters of the International Bill of Human Rights: of the seven, four are in the Universal Declaration but not the Covenants, while two are in the Covenants but not the Declaration; only one is in both.

\section{Human Rights Beyond the Nation-State}

Most substantive articles in the Declaration and the Covenants are intended to have universal application, and begin with phrases such as "All human 
being are ...", "Everyone has the right to ...", "No one shall be ...". In fact, though, there is an underlying assumption that these provisions regulate relations between citizens and their governments, reflecting the state-centric nature of contemporary world politics and international law. ${ }^{55}$

This state-centrism is evident in the absence of an international authority for the implementation and enforcement of international human rights instruments. ${ }^{56}$ States accept rather grand obligations to implement the rights enumerated in the Covenants, but for the most part each state government is the sole authoritative judge of the adequacy of its efforts. The enforcement of human rights norms rests largely on national, not international, action.

State-centrism is even more evident in the fact that almost all rights can be denied to nonnationals. For example, the derogation of economic, social, and cultural rights in the developing countries is explicitly permitted by Article 2(3) of the Covenant on Economic and Social Rights. Article 13 of the Covenant on Civil and Political Rights permits the expulsion of even lawfully resident aliens, so long as the expulsion is carried out according to law and the alien is permitted the opportunity to present arguments against the expulsion. In addition, although both Covenants prohibit discrimination on the basis of national or social origin, they do not prohibit discrimination on the basis of citizenship or legal nationality.

Nonetheless, the explicit exemption of developing countries from the obligation to extend economic and social rights to nonnationals implies that developed countries are not at liberty to deny these rights to nonnationals, or at least to those lawfully in their territory. In addition, aliens can argue for protection under the manifest meaning of international human rights provisions that are formulated to apply to "Everyone ..." or "All persons. ..." ${ }^{\prime 57}$ Thus, the Human Rights Committee, the independent body of experts that monitors compliance with the Covenant on Civil and Political Rights, has held that aliens are entitled to all the rights in the Covenant except those explicitly restricted to citizens or some other group..$^{58}$ The general thrust of

55. R. J. Vincent, Human Rights and International Relations (Cambridge: Cambridge University Press [for the Royal Institute of International Affairs], 1986): 150-52; and Richard Falk, "Theoretical Foundations of Human Rights," in Human Rights and State Sovereignty (New York: Holmes and Meier, 1980).

56. See Jack Donnelly, "International Human Rights: A Regime Analysis," International Organization 40 (Summer 1986): 599-642; and Egon Schwelb and Philip Alston, "The Principal Institutions and Other Bodies Founded Under the Charter," in The International Dimensions of Human Rights, ed. Karel Vasak and Philip Alston (Westport, CT: Greenwood Press, 1982).

57. Such an argument is strongly reinforced by the presence in other articles of alternative words clearly intended to exclude aliens: for example, Article 25 of the Civil and Political Covenant extends political rights (only) to "Every citizen ... ." and Article 12's protection of freedom of movement and residence applies only to "Everyone lawfully within the territory of a State," thus explicitly excluding illegal aliens from this protection.

58. Human Rights Committee, Report of the Human Rights Committee [1986], UN document number A41/40: 117-19. Compare Richard B. Lillich, The Human Rights of Aliens in Contemporary International Law (Manchester: Manchester University Press, 1984). 
the idea of nondiscrimination also seems to require the extension of full protection to aliens.

The ambiguous position of aliens, however, is underscored by the restriction of the right to freedom of movement to those lawfully within a state's territory by Article 12 of the Covenant on Civil and Political Rights. This clearly implies a state's right to restrict the entry of any nonnational it wishes (except perhaps if the restriction rests on prohibited grounds for discrimination). Similarly, Article 12(2), (4) of the Covenant on Civil and Political Rights explicitly guarantees to individuals the right to leave any country, but to enter only one's own country. ${ }^{59}$ The exclusion of nonnationals is subject to even fewer limitations than their expulsion. ${ }^{60}$ The only restriction on the state's right to exclude nonnationals is embodied in the right of asylum, recognized in Article 14 of the Declaration (but not in the Covenants).

The only provision in the entire International Bill of Human Rights that clearly is not restricted to a state's treatment of its own citizens is Article 28 of the Universal Declaration: "Everyone is entitled to a social and international order in which the rights and freedoms set forth in this Declaration can be fully realized." The most plausible reading of Article 28 is as an "elastic cause," to justify future extensions of new rights. As such, it is not surprising that it was not included in the Covenants, which unambiguously impose international legal obligations and establish nationally justiciable rights; it is extremely rare for lawmaking treaties to include such elastic provisions, which to most states seem extraordinarily dangerous due to the unpredictability of their application. This is especially true since the reference to international order might imply unspecified limitations on sovereignty. Taken seriously, it might lead to the acceptance of human rights obligations and, in particular, economic obligations to other states and the international community. Such obligations are scrupulously avoided almost everywhere else in the International Bill of Human Rights.

The struggle for a new International Economic Order or other obligatory mechanisms for the redistribution of international resources has given salience to Article 28 of the International Bill of Human Rights. It is certainly true that some impediments to the realization of human rights lie in the current international political and economic order-even if, as we have argued above, the principal impediments are national. But Article 28 is too vague, too controversial, and too much contrary to the rest of the Declaration and the Covenants to bear much weight. Nonetheless, it does address a set of problems largely outside the current state-centric framework of international human rights norms, and thus suggests a potentially important area for the further development of those norms.

59. See also UN document E/CN.4/Sub.2/1987/10.

60. Compare Animesh Ghoshal and Thomas M. Crowley, "Refugees and Immigrants: A Human Rights Dilemma," Human Rights Quarterly 5 (August 1983): 327-347. 
Human rights are the rights of each and every individual, simply as a human being. To make the realization and protection of these rights dependent on such arbitrary features as place of birth or the nationality of one's parents seems morally unjustifiable. Even it if is admitted that states are, and are likely to remain, the primary focus of whatever international order we have-that is, even if we allow that state-centrism is an international political fact to which even human rights norms must bend-it seems inappropriate to allow any of the fundamental structures of international order to interfere actively with the universal realization of human rights. Perhaps Article 28 reflects a glimmer of such concerns. In general, however, state-centrism is overwhelmingly dominant in the International Bill of Human Rights.

The fifth and final anomalous right in this group is the right to nationality, another right found in the Declaration (Article 15) but not the Covenants. In a world structured around sovereign states, the right to nationality is an essential minimum guarantee of membership in some society, and thus in the society of states. The right to nationality, along with the right to enter one's own country, assures that there is at least one place from which each person cannot be excluded. In a world of states, the stateless person is everywhere an outsider: ${ }^{61}$ as human beings, the stateless are entitled to all human rights, but no state takes responsibility to protect their rights, nor do they necessarily have the right to live in any country of the world. ${ }^{62}$

\section{The Right to Property}

Article 17 of the Universal Declaration reads: "1. Everyone has the right to own property alone as well as in association with others. 2. No one shall be arbitrarily deprived of his property." Similar provisions were discussed during the drafting of the Covenants, but in the end were not included because of an inability to achieve consensus on their formulation.

We advocate a limited right to property, but reject any attempt to attach the right to property to nonhuman entities such as business corporations. We would also subordinate any right to property to other human rights, in particular the right to food and the right to work not merely for a wage, but also under safe working conditions and at labor suitable for a human being. At the same time, however, we are aware of the abuses of individual workers and peasants that occur when private ownership is converted into public (state) ownership, especially in otherwise repressive societies. State own-

61. Compare Dorothy Jean Walker, "Statelessness: Violation or Conduit for Violation of Human Rights," Human Rights Quarterly 3 (February 1981): 106-123.

62. Although Article 24 of the International Covenant on Civil and Political Rights states that "every child has the right to acquire a nationality," in practice many children do not; for example, persons of Lebanese origin born in Sierra Leone, where citizenship is granted only to those of "negro-African" descent (Howard, note 36 above, 101) or ethnic Koreans born in Japan, who are legally aliens even if their families have lived in Japan for generations (Iwasawa, note 31 above). 
ership and management of productive property is not necessarily a better protector of the rights to food and to work - or any other rights - than private capitalist ownership.

Thus, we argue for the right to property under limited conditions: no individual or family should be deprived, either by private citizens, corporate entities, or the state, of the property that he or she, or the household unit, may own or control in order to produce food or an individual or household income. Nevertheless, we realize that even this principle cannot be translated into a hard and fast rule; for example, a family-held corporation or plantation could provide the family's sole source of income while employing thousands of workers in exploitative conditions.

The right to property should be accepted, but as an individual human (not corporate or state) right. Furthermore, there should be no human right (although, depending on the circumstances, there may be justifiable legal rights) to private ownership of means of production used for the sustenance of large numbers of other people.

\section{Self-Determination}

Both Covenants, in Article 1, declare that "all peoples have the right to selfdetermination" and the right to "freely dispose of their natural wealth and resources." This right is anomalous because it is the only right in the entire International Bill of Human Rights that is a right of "peoples" - meaning states in practice-not individuals. Academic commentators occasionally argue for a right of individual self-determination, but such a right, besides being obscure and extravagant, is not widely recognized, as demonstrated by the words of the Covenants. Furthermore, the "peoples" who are entitled to self-determination, according to accepted international practice, are only those currently or previously under colonial domination. The right to selfdetermination of nationalities or groups within established sovereign states is, for obvious reasons, strongly opposed by virtually all states. ${ }^{63}$

For people under foreign or colonial rule, self-determination is an important right. Normally, individuals prefer to be ruled by their "own kind" rather than by foreigners or outsiders. Self-determination in this sense is an aspect of human dignity: the knowledge that one's own people rule one's own country generates a sense of efficacy and pride.

But self-determination has no meaning as a human right, as distinct from an international legal right, if individuals are given no right to participate in their own governance, if they do not act as subjects determining their own lives, rather than mere objects of (independent) state policies. The millions of refugees fleeing their "own" countries are ample evidence that many

63. Michla Pomerance, Self-Determination in Law and Practice: The New Doctrine of the United Nations (The Hague: Martinus Nijhoff, 1982); and Lee C. Buchheit, Secession: The Legitimacy of Self-determination (New Haven: Yale University Press, 1978). 
people would rather live in security with strangers than in their "own" nationstates as victimized citizens. Homegrown oppressors may be preferable to foreign ones, but true self-determination requires autonomous political participation for all individuals. Self-determination, even for peoples rather than individuals, means more than a right to local despots.

Self-determination is undoubtedly an important right, but as it is formulated in the Covenants it is at best an anomaly, and at worst not a human right at all but rather an international legal right of states. As it is internationally interpreted, it is irrevelant as a protection of individuals against their own governments; worse, it is often used an an ideological tool for justifying, and deflecting outside criticism of, the abuse of citizens' human rights.

\section{CONCLUSION}

We have argued that ten key rights, taken together, can be used as proxies for almost the entire list of rights in the International Bill of Human Rights. This particular list certainly can be debated. For example, some commentators $^{64}$ would prefer to include the right to work. Others might argue that it is redundant to include both the right to an independent judiciary and the right to habeas corpus, or both the right to food and the right to health care. Our views on these matters are not cast in stone. We recognize the preliminary nature of this analysis.

Nevertheless, we consider it useful to open the debate, and believe that our initial effort here may be both theoretically and heuristically valuable. Any analysis of the protection or abuse of rights - or indeed of the policy issues raised by a commitment to human rights-must make some choices, implicit or explicit, about the right upon which to focus. It is time that we confront directly the issues involved in such a choice.

The next step is to take this (or a similar) framework and put it to use in empirical research. We hope to begin doing so ourselves in the near future, and hope that other social scientists will pursue similar or parallel lines of research.

Useful data for most of our key rights already exist or could be made available from existing public data sources. We would particularly like to see the creation of a public data bank based on this or a similar list of key rights. It is also important that alternative strategies for using such data be tried and evaluated. These might range from large-scale, crossnational, aggregate data analysis to matched-pair comparisons involving qualitative as well as quantitative data, and should include a variety of intermediate and mixed approaches as well. Such work should bring us one step closer to understanding the causes of respect for, and abuse of, human rights.

64. For example, Skalnes and Egeland, note 2 above. 